Marquette University

e-Publications@Marquette

College of Nursing Faculty Research and

Publications

Nursing, College of

$12-1-2011$

Perceptions of Professional Practice and Work Environment of New Graduates in a Nurse Residency Program

Marilyn Meyer Bratt

Marquette University, marilyn.bratt@marquette.edu

Holly M. Felzer

Marquette University, holly.felzer@marquette.edu

Accepted version. The Journal of Continuing Education in Nursing, Vol. 42, No. 12 (December 2011): 559-568. DOI. (C) 2011 Slack Incorporated. Used with permission. 


\title{
Perceptions of Professional Practice and Work Environment of New Graduates in a Nurse Residency Program
}

\author{
Marilyn Meyer Bratt \\ College of Nursing, Marquette University, \\ Milwaukee, WI \\ Holly M. Felzer \\ College of Nursing, Marquette University, \\ Milwaukee, WI
}

\section{Introduction}

The climate of health care is dramatically changing in the midst of escalating patient acuity. Plagued by budgetary restrictions, health care organizations are being forced to operate with less resources resulting in personnel cutbacks, shorter orientation programs and curtailed staff development activities. Delivering care in this practice environment is challenging for all providers, but particularly newly graduated nurses entering the workforce. New graduates' struggles are compounded due to the heightened demands for clinical expertise resulting in a steep learning curve and increased expectations for 
rapid role assimilation (Spector \& Li, 2007; Berkow, Virkstis, Stewart, \& Conway, 2008; Romyn et al.,2009).

New graduate nurses represent an increasing proportion of nursing staff in hospitals (IOM, 2011), but without standardized nurse residency programs many find the transition into acute care practice daunting ((Beecroft, Kunzman \& Krosek, 2002; Blanzola, Lindeman, \& King, 2004; Goode, Lynn, Krsek, \& Bednash, 2009; Lindsey \& Kleiner, 2005; Marcum \& West, 2004; Owens, et al., 2001; Rosenfeld, Smith, Iervolino, \& Bowar-Ferres, 2004; Williams, Sims, Burkhead, \& Ward, 2002). New nurses' high stress levels and their inexperience make them especially prone to error and turnover (Duchscher, 2008; Duchscher \& Cowin, 2004; Smith, 2003), thus exacerbating safety concerns on the patient care unit. Moreover, high numbers of inexperienced staff has been identified as another contributing factor of nurse turnover which also negatively influences patient health outcomes and safety (Beecroft, Dorey \& Wenten, 2007; Del Bueno, 2005; Orsolini-Hain \& Malone, 2007). Recommendations of a recent Institute of Medicine report (IOM, 2011) highlighted the seriousness of this situation and emphasized that health care organizations, as well as accrediting bodies, state boards of nursing, and the federal government, need to take actions to ensure that new graduate nurses receive better transition experiences. Implementation of nurse residency programs was one of the key report recommendations.

Health care organizations have been challenged to design effective programs that offer support for new graduates to ease their transition into practice (Lindsey \& Kleiner, 2005; Pine \& Tart, 2007). Nurse residency programs (newly licensed nurses' transition to practice programs) are an evolving evidence-based strategy to help new nurses bridge the practice gap, reduce turnover and enhance patient safety and quality of care (Beecroft et al., 2001; Bratt, 2009; Krugman et al., 2006; Romyn et al.,2009). Currently the National Council of State Boards of Nursing (NCSBN) is advocating for organizations to adopt a transition to practice regulatory model inclusive of all levels of licensed nurses and recommends that the completion of a transition program become criteria for relicensure after the first year of practice (NCSBN, 2009a). Furthermore, the Commission on Collegiate Nursing Education (2008) has recently 
established standards and an accreditation process for postbaccalaureate nurse residency programs.

Since nurse residency programs are a relatively recent phenomenon, the establishment of best practice around the structure and delivery of transition to practice programs is still evolving. To this end, a need exists to conduct research studies so that nurse residency programs are built on evidence. This evidence is necessary so that nurses in staff development can be guided by research findings as they institute transition to practice models that best promote competencybuilding in novice practitioners in order to optimize safe, quality care delivery. Therefore, this article describes a portion of the results from a series of investigations surrounding newly graduated nurses' transition to practice experiences from a sample of participants in the Wisconsin Nurse Residency Program (WNRP) (Bratt, 2009; Bratt \& Felzer, in press).

\section{Wisconsin Nurse Residency Program}

Stimulated by high turnover rates in the new graduate population staff development experts from nine health care organizations and an academic partner collaborated to create the Wisconsin Nurse Residency Program (WNRP). These organizations represent close to 50 urban and rural hospitals that ranged in size from a 700-bed teaching hospital to 25-bed critical access hospitals. Funded by a grant from Health Resources and Services Administration (HRSA) in 2004, the WNRP project team developed a structured program, including a program model, curriculum, and delivery methodologies that could be applied across diverse practice settings.

Launched in 2005, the WNRP is an educational and psychosocial support system for new graduate nurses over the course of one year. The program consists of mentoring and monthly all day professional development sessions provided by nurse experts and skilled facilitators, which was previously described in the literature (Bratt, 2009). These educational sessions are structured around topics designed to enhance new graduates' knowledge of their particular patient population, ability to function as part of a team, a member within the organization, and as a member of the profession. Designed 
to mitigate work environment factors that contribute to job dissatisfaction and turnover, the WNRP focuses on developing competent practitioners who can critically think, effectively make clinical decisions, engage in evidence based practice, and become leaders and lifelong learners.

Deployment of the program was accomplished through establishment of program sites comprised of single hospitals, several hospitals from one system, several community hospitals in the same geographic area, or multiple small rural hospitals that were organized under a health care consortium (Rural Wisconsin Health Cooperative). Each location had a designated site coordinator who underwent a specialized orientation and received focused training in facilitation skills and teaching modalities to insure consistency in program delivery at each site. Site coordinators were also members of the WNRP project implementation team, which met monthly to discuss ongoing program execution, evaluation and quality improvement efforts. These monthly meetings provided a strong supportive network for site coordinators that were geographically dispersed.

Nurse residents, managers, and hospital administrators have been extremely satisfied with the WNRP. Outcome data have revealed powerful gains relative to new graduates' retention, clinical competency, and ability to "think like a nurse" (Bratt, 2009). Qualitative data from nurse residents demonstrated that the program enhanced their confidence and ability to manage patient care assignments, make better decisions, effectively use their resources, and avoid failure to rescue situations. For new nurses practicing in rural settings, the WNRP was particularly effective in minimizing their sense of isolation and providing a professional network.

Health care organizations have reaped significant benefits as a result of the academic-service partnership by sharing resources, intellectual property, education innovations and best staff development practices (Bratt, 2009). Nursing administrators have verbalized that this project has added value by building capacity across multiple levels of nurses within their organization. Staff development specialists participating on the implementation team, unit-based educators, and experienced nurses who engage in the daily learning of new graduates 
have undergone professional and personal growth. For these organizations, the WNRP project has been transformative, revolutionizing new graduate orientation processes and accelerating the building of clinical expertise in beginning nurses.

\section{Methodology of The Study}

The specific aim of this study was to examine newly licensed nurses' perceptions of their professional practice including decisionmaking ability and quality of nursing performance and work environment factors including job satisfaction, job stress, and organizational commitment over a 12-month period.

\section{Design and Procedure}

This study used a repeated measures design to compare new graduates' perceptions of their work environment and professional practice throughout a one-year nurse residency program. Following IRB approval, data were collected at baseline (beginning of the residency program approximately three months after hire), six months following the baseline measure (program midpoint), and twelve months (endpoint) at the conclusion of the residency program.

\section{Sample}

The total sample consisted of 468 newly licensed registered nurses employed in acute care hospital settings who were participants in the Wisconsin Nurse Residency Program (WNRP) from 2005-2008. Since the study used a repeated measures design, a sub-sample of participants with complete data sets was used for analysis. These participants were employed by large multi-hospital systems, community-based hospitals in urban and rural settings, and critical access hospitals. Depending on the employing organization, program participants were selected via an application process or the program was mandatory for all new graduates. Participation was not restricted based on type of nursing degree and new graduates attended the program on paid time. 
NOT THE PUBLISHED VERSION; this is the author's final, peer-reviewed manuscript. The published version may be accessed by following the link in the citation at the bottom of the page.

\section{Measures}

New graduates' perceptions of their professional practice competency were measured by two instruments. The first, Clinical Decision Making in Nursing Scale (CDMNS) (Jenkins, 1985), is a 40item instrument rated on a five-point Likert scale ( 1 = never; $5=$ always) that measures the conscious, cognitive method of how one goes about making decisions including searching for alternatives and options, canvassing objectives and values, evaluating and reevaluating consequences, and searching for information and unbiased assimilation of new information. Total scale Cronbach's alpha for the study sample was $0.82-0.83$. The second instrument, the Modified 6-D Scale of Nursing Performance, is a measure of quality of nursing performance that was developed by Schwirian (1978) and revised by Marshalleck (1997). It contains 61 items on a five-point Likert scale ( $0=$ not applicable; 4 = very well) and includes seven subscales: critical care, interpersonal relations/communications, leadership, managing/outcomes, planning/evaluation, professional development, and teaching/collaboration (Cronbach's alpha for the study sample: total scale $a=0.95$; subscales $a=0.71-0.90)$.

New graduates' perceptions of their work environment were measured using three instruments. The Nurse Job Satisfaction Scale (Hinshaw \& Atwood, 1985) measures elements that are important to enjoying or liking one's job. This scale contains 23 items on a fivepoint Likert Scale ( 1 = strongly disagree; $5=$ strongly agree) and is comprised of three subscales including quality of care, enjoyment, and time to provide care (for the study sample, total scale $a=0.90$; subscales $a=0.77-0.90$ ). The Job Stress Scale (Hinshaw \& Atwood, 1985) measures stress that is perceived in relationship to one's job and work environment. This 22-item scale is rated on a four-point Likert scale ( $1=$ always; $4=$ rarely) and is comprised of four subscales: competence, physical work environment, staffing, and team respect (for the study sample, total scale $a=0.87$; subscales $a=0.64$ - 0.81). Finally, the Organizational Commitment Questionnaire (Mowday, Steers \& Porter, 1979) measures the relative strength of an individual's identification with and involvement in a particular organization. This instrument has been shown to also be a viable indicator of turnover intent (Wagner, 2007). The instrument is 
NOT THE PUBLISHED VERSION; this is the author's final, peer-reviewed manuscript. The published version may be accessed by following the link in the citation at the bottom of the page.

comprised of 15 items on a seven-point Likert scale ( 1 = strongly disagree; 7 = strongly agree) (for the study sample, total scale $\mathrm{a}=$ $0.90-0.91)$.

\section{Data Analysis}

Descriptive and inferential statistical methods were employed to analyze the data. Demographic statistics are reported for the entire sample. Analysis of differences across time included only those participants who had completed survey instruments at the three measurement times: baseline, six months, and twelve months. All analyses were carried out using SPSS (Version 17.0) statistical software. A one-way repeated measures ANOVA was calculated comparing the total scale scores and subscale scores at each of the three data collection times. Because some participants did not participate in all of the measurement points (due to absence or choice), independent sample t-tests and chi square analyses (as appropriate) were performed to determine if there were any significant differences in demographic characteristics or outcome variables between participants who provided complete data sets (at the three measurement points) and those who did not provide data at one or two of the measurement points.

\section{Results}

\section{Demographic Characteristics}

The total sample was comprised of 468 nurse residents with a mean age of 30 years ( $S D=8.3$ ). They were from primarily urban hospitals who were predominantly Caucasian females with associate degrees working on medical-surgical units as outlined in Table 1 . The subsample of nurses who completed surveys at all three time periods was $n=227(48.5 \%)$ of the total sample. Of those with incomplete data sets ( $n=241), 170(70.5 \%)$ completed surveys at baseline, 112 $(46.5 \%)$ at six months, and $89(36.9 \%)$ at twelve months.

Journal of Continuing Education in Nursing, Vol. 42, No. 12 (December 2011): pg. 559-568. DOI. This article is @ Slack Incorporated and permission has been granted for this version to appear in e-Publications@Marquette. Slack Incorporated does not grant permission for this article to be further copied/distributed or hosted elsewhere without the express permission from Slack Incorporated. 
NOT THE PUBLISHED VERSION; this is the author's final, peer-reviewed manuscript. The published version may be accessed by following the link in the citation at the bottom of the page.

\section{Participant Outcomes over Time}

Results from the within-subjects repeated measures ANOVA of outcomes reported by participants providing data at all data points are summarized in Table 2. Post hoc analysis revealed significant effects over time on all measures, which are explained below.

Clinical Decision Making: Clinical decision making scores were significantly higher at twelve months than at six months, though no differences were evident between baseline and the six-month midpoint or baseline and twelve months.

Job Satisfaction: Total scale scores for job satisfaction were significantly higher at twelve months than at baseline or six months. Similar results were obtained for quality of care and time to provide care subscales. The enjoyment subscale, however, declined from baseline to midpoint.

Job Stress: At program conclusion, job stress scores were significantly lower than baseline or midpoint. Differences between job stress scores at baseline compared to midpoint were not significant. Stress related to personal factors of feeling a respected part of a team (team respect subscale) and perceptions of individual competence, clinical knowledge and judgments (competence subscale) significantly decreased over time. Conversely, stress related to environmental factors such as having adequate supplies and workspace (physical environment subscale) and adequacy of staffing to provide quality care and have a satisfying work schedule (staffing subscale) increased from baseline to midpoint. Staffing-related stress then declined from the six month midpoint to the twelve month endpoint.

Organizational Commitment: Commitment to the organization was significantly higher at baseline than six months and program completion at twelve months.

Quality of Nursing Performance: For the total Modified 6-D Scale of Nursing Performance scale and all subscales, there was a consistent significant upward trend of mean scores over time between all measurement points.

Journal of Continuing Education in Nursing, Vol. 42, No. 12 (December 2011): pg. 559-568. DOI. This article is @ Slack Incorporated and permission has been granted for this version to appear in e-Publications@Marquette. Slack Incorporated does not grant permission for this article to be further copied/distributed or hosted elsewhere without the express permission from Slack Incorporated. 


\section{Comparison between Group Differences for Participants with Complete and Incomplete Data Sets}

Among the participant characteristics, only two significant differences were found. Participants with incomplete data ( $\mathrm{n}=225 ; \mathrm{m}$ $=30.9, \mathrm{SD}=8.4$ ) were older than those with complete data $(\mathrm{n}=227$; $\mathrm{m}=29.1, \mathrm{SD}=8.2 ; \mathrm{t}(450)=2.286 ; \mathrm{p}=.02)$. Participants with complete data were more likely to feel that their orientation was adequate $(92 \%)$ than were those with incomplete data $(86 \%)\left(X^{2}(1)=\right.$ $4.01, p=.04)$. Results of group comparisons of outcome measures are summarized in Table 3. Participants who completed all surveys during the year long program had higher clinical decision-making scores at twelve months, higher job satisfaction and organizational commitment at all time points, and lower scores of job stress at baseline and six months compared to those that did not complete all three surveys. No differences were found between the groups on perceptions of the quality of nursing performance.

\section{Discussion}

\section{Demographic Data}

The sample represents diversity of educational backgrounds of new licensees. Of interest is that almost $22 \%$ of the participants had a previous non-nursing degree. This may account for the mean age of the sample. This is similar to findings of Altier and Krsek (2006) who reported that $25 \%$ of their participants held previous non-nursing degrees. Associate degree nurses were in the majority, which is not surprising as the majority of participants practiced in rural hospitals or non-academic medical centers located outside of large metropolitan areas and the residency program was not restricted to baccalaureate prepared nurses.

\section{Differences within Participants over Time}

The findings revealed that upon completion of the residency program, participants had higher means of job satisfaction, clinical 
decision-making ability, quality of nursing performance, and organizational commitment, and lower means of stress compared to baseline and /or six month levels. The six month decline in job satisfaction, organizational commitment, and clinical decision-making are consistent with findings in the literature (Altier \& Krsek, 2006; Duchscher, 2008; Casey, Fink, Krugman \& Propst, 2004; Goode, et al., 2009; Krugman et al., 2006). In particular, Casey et al. (2004) found that the most difficult role adjustment time was between six to twelve months after hire. These finding underscore the vulnerability of new graduates to leave their positions and the criticalness of providing continued support throughout the first year of practice. Perceptions that clinical decision making improved by program end provides critical evidence that transition to practice programs can enhance new graduates' ability to make patient care decision but also has a secondary benefit because this competency is also linked to job satisfaction (Zurmehly, 2008).

Perceptions of clinical decision-making, which were lowest at midpoint, may be best explained in terms of Duchsher's stage of "being" in her new graduate role transition model. Duchsher (2008) asserts that new graduates are aware of their knowledge gaps and confidence in their clinical judgments is tenuous characterized by a need to validate their thinking. According to Duchscher, the peak time of difficulty and "crisis of confidence" occurred at five to seven months. This need for validation of thinking from experienced peers and a practice environment that supports clinical thought processes has been identified by Benner, Tanner and Chesla (2009) and O'Neill, Dluhy, and Chin (2005). Casey and colleagues (2004) also found that feelings of inadequacy in clinical knowledge and fear related to making patient care decisions were prevalent throughout the first year of practice. Furthermore, initially new graduates initially rated themselves as being comfortable in their role; however, at three to twelve months this confidence declined (Casey et. al, 2004)

Interestingly, the finding that job stress was significantly lowest at endpoint was consistent with previous studies (Goode et al., 2009; Krugman, et al., 2006); however, these studies did not support the finding of the significant increase in job stress at midpoint compared to baseline and endpoint. Further examining the sources of job stress 
through the analysis of the subscales, it was apparent that the predominant stress factors changed over time. Baseline stress subscale scores revealed that stress was generated from struggles around personal competence and gaining team respect, whereas, stress at midpoint and endpoint was predominantly generated by external, environmental factors of workload and staffing issues.

Duchsher (2008) found that during the middle and final stages of transition factors impacting new graduates' stress changed from difficulties coping with roles and responsibilities to frustrations in dealing with system issues. Similarly, Kramer's Reality Shock Model (1974) explains that during the shock phase, new graduates struggle with providing quality care and a realization of their unpreparedness to manage their workload. This finding was also supported by Berkow et al. (2008) who surveyed front-line leaders to determine satisfaction with new graduates' proficiency across 36 competencies grouped into six broad categories. Administrators were found to be least satisfied with new graduates' competency related to managing responsibilities of patient care and critical thinking. The incremental increase in quality of performance of nursing behaviors that was observed in the present study is expected as new graduates undergo rapid skill acquisition and development of competency during the first year of practice, which has been supported in other studies (Casey et al., 2004; NCSBN, 2009b).

What is somewhat disconcerting is that organizational commitment scores at program end were not significantly higher than baseline measures. This may reflect that new graduates are still in the shock phase and grappling with their professional role transition and have yet to enter the resolution and recovery phases as identified by Kramer (1974) and Duchscher (2008). However, significant increases from midpoint to program end does lend support for the value of residency programs since it may demonstrate the influence of the program to expedite the new graduates' recovery of disillusionment and questioning that occurs in this middle phase of the transition experience. For organizations, it does call attention to the need to continue monitoring new graduate turnover intention and sustain environmental support systems to decrease stress and increase job satisfaction.

Journal of Continuing Education in Nursing, Vol. 42, No. 12 (December 2011): pg. 559-568. DOI. This article is @ Slack Incorporated and permission has been granted for this version to appear in e-Publications@Marquette. Slack Incorporated does not grant permission for this article to be further copied/distributed or hosted elsewhere without the express permission from Slack Incorporated. 


\section{Differences between Participants with Complete and Incomplete Data Sets}

Regarding differences between participants with complete and incomplete data sets, it is interesting to note that those with incomplete data sets had significantly lower means of job satisfaction and organizational commitment at each measurement point and higher means of job stress at baseline and six months compared to those with complete data sets. Additionally this group was less satisfied with their orientation, which may have resulted in a more global perception of dissatisfaction leading to diminishment in commitment to the organization. Of particular interest is those with incomplete data had lower mean scores of clinical decision making at program end. The cause of these differences is unknown, but it may point to a relationship between this group of participants' relative investment and involvement in the residency program. It is possible that those with incomplete data sets were not fully engaged in the residency program and consequently did not reap the benefits of participation such as improved decision-making, enhanced job satisfaction and decreased stress, which were the intended outcomes of the program.

\section{Support for Transition to Practice Programs}

This study adds to the growing body of evidence that demonstrates the efficacy of transition to practice programs (Beecroft et al., 2007; Beyea, von Reyn, \& Slattery, 2007; Fink, Krugman, Casey \& Goode, 2008; Goode et al., 2009; Salt, Cummings, \& Profetto-McGrath, 2008; Williams, Goode, Krsek, Bednash \& Lynn, 2007). In this study it was apparent that nurses who were fully invested in the program had better outcomes than those who were not. New graduates participating in the residency program did demonstrate positive gains in clinical performance over time and had more positive perceptions of their work environment at program end. Nurse residency programs offer essential professional development for newly licensed nurses and as such they can provide the important link between education/training and improvements in the work environment and organizational commitment (Baernholdt \& Mark, 2009; Bartlett, 2001). 
NOT THE PUBLISHED VERSION; this is the author's final, peer-reviewed manuscript. The published version may be accessed by following the link in the citation at the bottom of the page.

\section{Limitations}

The non-experimental design of this study is a limitation. Participants served as their own control in a single sample design. Therefore, it is difficult to ascertain whether the positive changes in the variables were attributed to the intervention of the residency program. Other unique organizational factors, such as onboarding and orientation practices may have contributed to these differences. Additionally, the residency program was situated within the acute care practice setting. It is unknown whether these trends will persist with a residency program targeted to nurses in other settings, such as longterm care. It is also unknown what specific methodological elements of the residency program may have accounted for the observed changes. Moreover, even though attempts were made to insure consistent program delivery, there may have been variability across sites.

Several potential threats to internal validity were present in this study. Respondent fatigue and burden in completion of the research instruments could have reduced the accuracy of responses. Respondents completed the same questionnaires at all three times; therefore, familiarity with questions and response recall could bias results. Participant attrition may also have influenced the results.

Participation in the study was voluntary, which may have contributed to selection basis. Since the study instruments are self reports, there is potential for social desirability response bias.

Additionally, although the study included multiple practice sites, the majority of participants were Caucasian females, which may place limits upon the generalizability of findings.

\section{Recommendations for Practice}

\section{Administrators/Nurse Managers}

There is mounting evidence on the efficacy of transition to practice programs and the inherent cost-saving in relationship to decreased turnover of the new graduate nurse population (Pine \& Tart, 2007). However, the viability of transition programs is contingent upon allocation of appropriate resources. In the wake of budget cuts and

Journal of Continuing Education in Nursing, Vol. 42, No. 12 (December 2011): pg. 559-568. DOI. This article is @ Slack Incorporated and permission has been granted for this version to appear in e-Publications@Marquette. Slack Incorporated does not grant permission for this article to be further copied/distributed or hosted elsewhere without the express permission from Slack Incorporated. 
economic downturn, there needs to be continued expenditures to support this new generation of nurses. New graduates need to be placed in positive unit cultures that are conducive to meeting their learning needs and have sufficient numbers of highly competent clinicians to guide their practice and thinking processes. Access to experienced nurses throughout the first year is paramount to assist in developing their clinical judgment.

\section{Staff Development/Educators}

Due to the evident trends at the six month period of time, particularly low levels of job satisfaction, organizational commitment, and clinical judgment and persistent high levels of stress, transition to practice programs need to last longer than six months to help new graduates weather this tumultuous time period. Transition programs need to not only enhance new graduates' clinical knowledge base and judgment skills, but also employ strategies to mitigate job stress. Professional development and skill building throughout the first year of practice is essential due to new graduates' persistent difficulties managing their increasing work load and shifting priorities of care and evolving their clinical judgment skills, all of which creates potential patient safety risks. This is best provided by a structured transition to practice/nurse residency program guided by skilled facilitators and expert nurses that guide new graduates' evolving clinical expertise. Due to new graduates' heavy reliance on experienced nurses to develop clinical competence, it is essential that they spend sufficient time with skilled preceptors. Staff development efforts need to be directed towards creating an adequate and well-trained pool of preceptors that are able to effectively deploy techniques that promote new graduates' role assimilation and ability to deliver safe care. Finally, since reduction in new graduate turnover is a compelling outcome of transition programs, it is critical to establish a mechanism to track new graduates' retention rates and determine the cost-benefit ratio of a transition program.

\section{Researchers}

Even though evidence related to nurse residency/transition to practice programs is beginning to accumulate, there is still insufficient

Journal of Continuing Education in Nursing, Vol. 42, No. 12 (December 2011): pg. 559-568. DOI. This article is @ Slack Incorporated and permission has been granted for this version to appear in e-Publications@Marquette. Slack Incorporated does not grant permission for this article to be further copied/distributed or hosted elsewhere without the express permission from Slack Incorporated. 
research, particularly studies that feature quasi-experimental designs, resulting in inconclusive evidence for the structure of strategies that promote new graduate retention (Salt et al., 2008; Newhouse, Hoffman, \& Hairston, 2007). Further studies are needed to more fully explore the effects of these programs, particularly longitudinally, and uncover core essential elements that contribute to the success of these programs so as to establish best practices. Moreover, studies of transition to practice programs need to be conducted across diverse practice settings and engage in further exploration of the program outcomes, particularly the influence on quality of care and the practice environment.

\section{Summary}

Nearly forty years after Marlene Kramer's acclaimed study (1974), many aspects of new graduates' entry to practice experience remain unchanged. It is evident that their work environments are still stressful and new nurses' job satisfaction and commitment wanes, particularly at the 6-9 month time period. Perhaps stress is a pervasive characteristic of nurses' work setting; one that is not easily changed. However, long-standing staff development practices can be changed so that they better sustain new nurses during their role transition. Long-term strategies extending beyond the typical 8-12 weeks of orientation need deployment to increase new graduates' professional competency and stress resiliency so that new graduates do not become dissatisfied and feel compelled to leave their first job.

In conclusion, there is a national mandate to provide residency programs for newly licensed nurses; a mandate that is capturing the attention of education and practice. Nurse residency programs are not standardized and little evidence exists as to the comparative effectiveness of particular models, curricula or delivery modalities. Health care administrators need such evidence to develop and maintain successful programs, as well as to justify the allocation of resources in a time of staffing shortages and financial constraints. Only through continued research with comparative analysis of different program structures and longitudinal exploration of outcomes will there be an emergence of best practices that drive the creation of quality nurse residency programs.

Journal of Continuing Education in Nursing, Vol. 42, No. 12 (December 2011): pg. 559-568. DOI. This article is @ Slack Incorporated and permission has been granted for this version to appear in e-Publications@Marquette. Slack Incorporated does not grant permission for this article to be further copied/distributed or hosted elsewhere without the express permission from Slack Incorporated. 
NOT THE PUBLISHED VERSION; this is the author's final, peer-reviewed manuscript. The published version may be

\section{References}

Altier, M. E., \& Krsek, C. A. (2006). Effects of a 1-year residency program on job satisfaction and retention of new graduate nurses. Journal for Nurses in Staff Development, 22(2), 70-77.

Baernholdt, M., \& Mark, B. A. (2009). The nurse work environment, job satisfaction and turnover rates in rural and urban nursing units. Journal of Nursing Management, 17, 994-1001.

Bartlett, K. R. (2001). The relationship between training and organizational commitment: A study in the health care field. Human Resource Development Quarterly, 12(4), 335-352.

Beecroft, P. C., Dorey, F., \& Wenten, M. (2007). Turnover intention in new graduate nurses: a multivariate analysis. Journal of Advanced Nursing, 62(1), 41-52.

Beecroft, P. C., Kunzman, L., \& Krozek, C. (2001). RN Internship: Outcomes of a one-year pilot program. Journal of Nursing Administration, 31(12), 575-582.

Benner, B., Tanner, C., \& Chesla, C. (2009). Expertise in Nursing Practice: Caring, Clinical Judgment and Ethics (2 ${ }^{\text {nd }}$ ed.), New York: Springer.

Berkow, S., Virkstis, K., Stewart, J., \& Conway, L. (2008). Assessing new graduate nurse performance. Journal of Nursing Administration 38(11), 468-474.

Beyea, S. C., von Reyn, L., \& Slattery, M. J. (2007). A nurse residency program for competency development using human patient simulation. Journal for Nurses in Staff Development, 23(2), 7782.

Blanzola,C. , Lindeman, R. , \& King, L. (2004) Nurse internship pathway to clinical comfort, confidence, and competency. Journal for Nurses in Staff Development, 20(1), 27-37.

Bratt, M. M. (2009). Retaining our next generation of nurses: The Wisconsin nurse residency program providing a continuum of support. Journal of Continuing Education in Nursing, 40(9), 416425.

Bratt, M. M., \& Felzer, H. M. (in press). Predictors of new graduate nurses' organizational commitment during a nurse residency program. Journal for Nurses in Staff Development.

Journal of Continuing Education in Nursing, Vol. 42, No. 12 (December 2011): pg. 559-568. DOI. This article is @ Slack Incorporated and permission has been granted for this version to appear in e-Publications@Marquette. Slack Incorporated does not grant permission for this article to be further copied/distributed or hosted elsewhere without the express permission from Slack Incorporated. 
Casey, K., Fink, R., Krugman, M., \& Propst, J. (2004). The graduate nurse experience. Journal of Nursing Administration, 34(6), 303-311.

Commission on Collegiate Nursing Education (2008). Standards for Accreditation of Post-Baccalaureate Nurse Residency Programs. Retrived from http://www.aacn.nche.edu/accreditation/pdf/resstandards08.pdf Del Bueno, D. (2005). A crisis in critical thinking. Nursing Education Perspectives, 26(5), 278-282.

Duchscher, J. B. (2008). A process of becoming: The stages of new nursing graduate professional role transition. Journal of Continuing Education in Nursing, 39(10), 441-450.

Duchscher, J. B., \& Cowin, L. S. (2004). The experience of marginalization in new nursing graduates. Nursing Outlook, 52, 289-296.

Fink, R., Krugman, M., Casey, K., \& Goode, C. (2008). The graduate nurse experience: Qualitative residency program outcomes. Journal of Nursing Administration, 38(7/8), 341-348.

Goode, C. J., Lynn, M., Krsek, C., \& Bednash, G. D. (2009). Nurse residency programs: An essential requirement for nursing. Nursing Economic\$, 27(3), 142-159.

Hinshaw, A. S., \& Atwood, J. R. (1985). Anticipated turnover among nursing staff study: Final report. National Institutes of Health. National Center of Nursing Research. No. R01NU00908.

Institute of Medicine (IOM). (2011). The future of nursing: Leading change, advancing health. Washington, DC: The National Academies Press. Retrieved February 1, 2011 from http://books. nap. edu/catalog/12956. html

Jenkins, H. M. (1985). A research tool for measuring perceptions of clinical decision making. Journal of Professional Nursing, 1(4), 221-229.

Kramer, M. (1974). Reality Shock: Why Nurses Leave Nursing. St. Louis, MO: CV Mosby.

Krugman, M., Bretschneider, J., Horn, P. B., Krsek, C. A., Moutafis, R. A., \& Smith, M. O. (2006). The national post-baccalaureate graduate nurse residency program: A model for excellence in transition to practice. Journal for nurses in staff development, 22(4), 196-205.

Journal of Continuing Education in Nursing, Vol. 42, No. 12 (December 2011): pg. 559-568. DOI. This article is @ Slack Incorporated and permission has been granted for this version to appear in e-Publications@Marquette. Slack Incorporated does not grant permission for this article to be further copied/distributed or hosted elsewhere without the express permission from Slack Incorporated. 
Lindsey, G., \& Kleiner, B. (2005). Nurse residency program: An effective tool for recruitment and retention. Journal of Health Care Finance, 31(3), 25-32.

Marcum, E. H., \& West, R. D. (2004). Structured orientation for new graduates. Journal for Nurses in Staff Development, 20(3), 118124.

Marshalleck, E. F. (1997). The effect of education, job characteristics, and hospital unit structure on nurse performance and job satisfaction. Unpublished doctoral dissertation, Stanford University.

Mowday, R. T., Steers, R. M., \& Porter, L. W. (1979). The measurement of organizational commitment. Journal of Vocational Behavior, 14, 224-247.

National Council of State Boards of Nursing (2009a). Description of NCSBN's Transition to Practice Model. Retrieved from https://www.ncsbn.org/TransitiontoPractice_modeldescription_1 11309.pdf .

National Council of State Boards of Nursing (2009b). Report of Findings from the Post-Entry Competency Study. Research Brief, Vol. 38. Retrieved from https://www.ncsbn.org/09_PostEntryCompetenceStudy_Vol38.p df

Newhouse, R. P., Hoffman, J. J., \& Hairston, D. P. (2007). Evaluating an innovative program to improve new nurse graduate socialization into the acute health care setting. Nursing Administration Quarterly, 31(1), 50-60.

O'Neill, E. S., Dluhy, N. M., \& Chin, E. (2005). Modeling novice clinical reasoning for a computerized decision support system. Journal of Advanced Nursing, 49(1), 68-77.

Orsolini-Hain, L., \& Malone, R. E. (2007). Examining the impending gap in clinical nursing expertise. Policy, Politics \& Nursing Practice, 8(3), 158-169.

Owens, D., Turjanica, M. A. , Scanion, M. W. , Sandhusen, A. E., Williamson, M. , Hebert, C., \& Facteau, L. (2001) New graduate RN internship program: A collaborative approach for systemwide integration Journal for Nurses in Staff Development, 17(3), $144-150$ 
Pine, R., \& Tart, K. (2007). Return on investment: Benefits and challenges of a baccalaureate nurse residency program. Nursing Economic\$, 25(1), 13-39.

Romyn, D. M., Linton, N., Giblin, C., Hendrickson, B., Limacher, J. H., Murray, C., Nordstron, P.,... Zimmel, C. M. (2009). Successsful transition of the new graduate nurse. International Journal of Nursing Education Scholarship, 6(1), 1-17.

Rosenfeld, P., Smith, M. O., Iervolino, L., \& Bowar-Ferres, S. (2004). Nurse resident program: A 5-year evaluation from the participant's perspective. Journal of Nursing Administration, 34(4), 188-194.

Salt, J., Cummings, G. C., \& Profetto-McGrath, J. (2008). Increasing retention $f$ new graduate nurses: A systematic review of interventions by health care organizations. Journal of Nursing Administration, 38(6), 287-296.

Schwirian, P. M. (1978). Evaluating the performance of nurses: A multidimensional approach. Nursing Research, 27(6), 347-351.

Smith, J., \& Crawford, L. (2003). Medication errors and difficulty in first patient assignments of newly licensed nurses. JONA's Healthcare Law, Ethics, and Regulation, 5(3), 65-67.

Spector, N., \& Li, S. (2007). A regulatory model on transitioning nurses from education to practice. JONA's Health care Law, Ethics, and Regulation, 9(1), 19-22.

Wagner, C. M. (2007). Organizational commitment as a predictor variable in nursing turnover research: Literature review. Journal of Advanced Nursing, 60(3), 235-247.

Williams, C. A., Goode, C. J., Krsek, C., Bednash, G. D., \& Lynn, M. R. (2007). Postbaccalaureate nurse residency 1-year outcomes. Journal of Nursing Administration, 37(7/8) 357-365.

Williams, T., Sims, J., Burkhead, C. \& Ward, P. M. (2002). The creation, implementation, and evaluation of a nurse residency program through a shared leadership model in the intensive care setting. Dimensions of Critical Care Nursing, 21(4), 154162.

Zurmehly, J. (2008). The relationship of educational preparation, autonomy, and critical thinking to nursing job satisfaction. The Journal of Continuing Education in Nursing, 39(10): 453-460.

Journal of Continuing Education in Nursing, Vol. 42, No. 12 (December 2011): pg. 559-568. DOI. This article is @ Slack Incorporated and permission has been granted for this version to appear in e-Publications@Marquette. Slack Incorporated does not grant permission for this article to be further copied/distributed or hosted elsewhere without the express permission from Slack Incorporated. 
NOT THE PUBLISHED VERSION; this is the author's final, peer-reviewed manuscript. The published version may be accessed by following the link in the citation at the bottom of the page.

Table 1: Sample Characteristics

\begin{tabular}{|c|c|}
\hline Demographic and Job Characteristics & $\begin{array}{l}\text { Total Sample } \\
N=468 *\end{array}$ \\
\hline & $\mathbf{N}(\%)$ \\
\hline $\begin{array}{l}\text { Gender } \\
\text { Female } \\
\text { Male } \\
\end{array}$ & $\begin{array}{r}428(94.3 \%) \\
26(5.7 \%) \\
\end{array}$ \\
\hline $\begin{array}{l}\text { Race } \\
\text { Asian } \\
\text { Black } \\
\text { Hispanic/Latino } \\
\text { White } \\
\text { More than one race } \\
\end{array}$ & $\begin{array}{r}3(0.7 \%) \\
16(3.5 \%) \\
8(1.8 \%) \\
414(91.6 \%) \\
11(2.4 \%) \\
\end{array}$ \\
\hline $\begin{array}{r}\text { Degree } \\
\text { ADN } \\
\text { BSN } \\
\end{array}$ & $\begin{array}{l}250(55.4 \%) \\
201(44.6 \%)\end{array}$ \\
\hline $\begin{array}{l}\text { Prior Non-nursing Degree } \\
\text { Yes } \\
\text { No }\end{array}$ & $\begin{array}{l}100(23.7 \%) \\
322(76.3 \%)\end{array}$ \\
\hline $\begin{array}{l}\text { Type of Hospital } \\
\text { Rural } \\
\text { Urban } \\
\end{array}$ & $\begin{array}{r}86(18.4 \%) \\
382(81.6 \%) \\
\end{array}$ \\
\hline $\begin{array}{l}\text { Type of Unit } \\
\text { Med-Surg } \\
\text { OB } \\
\text { ICU } \\
\text { ER } \\
\text { Surgical Services (OR, PACU, SDS) } \\
\text { Other Specialties (e.g. Oncology) }\end{array}$ & $\begin{array}{r}243(57.4 \%) \\
29(6.9 \%) \\
17(4.0 \%) \\
15(3.5 \%) \\
8(1.9 \%) \\
110(26.0 \%)\end{array}$ \\
\hline
\end{tabular}

*Ns for some analyses less than 468 due to missing data

Journal of Continuing Education in Nursing, Vol. 42, No. 12 (December 2011): pg. 559-568. DOI. This article is @ Slack Incorporated and permission has been granted for this version to appear in e-Publications@Marquette. Slack Incorporated does not grant permission for this article to be further copied/distributed or hosted elsewhere without the express permission from Slack Incorporated. 
NOT THE PUBLISHED VERSION; this is the author's final, peer-reviewed manuscript. The published version may be accessed by following the link in the citation at the bottom of the page.

Table 2: Repeated Measures ANOVA Participant Outcomes: ( $\mathbf{N}=227$ [Participants with Complete Data Sets])

\begin{tabular}{|c|c|c|c|c|}
\hline $\begin{array}{l}\text { Scale } \\
\text { Subscale }\end{array}$ & $\begin{array}{c}\text { Time 1 } \\
\text { Baseline } \\
\text { Mean(SD) }\end{array}$ & $\begin{array}{c}\text { Time } 2 \\
6 \text { Months } \\
\text { Mean(SD) }\end{array}$ & $\begin{array}{c}\text { Time } 3 \\
12 \\
\text { Months } \\
\text { Mean } \\
\text { (SD) }\end{array}$ & $\begin{array}{c}\text { Test Statistics } \\
\text { (Time of } \\
\text { Significant } \\
\text { Differences) }\end{array}$ \\
\hline Clinical Decision Making & $144.2(10.8)$ & $143.0(10.5)$ & $\begin{array}{l}145.1 \\
(10.4)\end{array}$ & $\begin{array}{l}F(2,154)=6.91 \\
p=.001(c)\end{array}$ \\
\hline $\begin{array}{l}\text { Job Satisfaction } \\
\text { Quality of Care } \\
\text { Time to Provide Care } \\
\text { Enjoyment }\end{array}$ & $\begin{array}{l}82.1(10.9) \\
25.3(4.3) \\
14.2(3.7) \\
42.6(5.2)\end{array}$ & $\begin{array}{l}81.0(10.9) \\
25.3(4.0) \\
14.2(3.6) \\
41.5(6.0)\end{array}$ & $\begin{array}{l}83.7 \\
(10.8) \\
26.4(4.0) \\
15.2(3.5) \\
42.1(5.6)\end{array}$ & $\begin{array}{l}F(2,225)=8.35 \\
p<.001(b, c) \\
F(2,225)=9.96 \\
p<.001(b, c) \\
F(2,225)= \\
11.76 \\
p<.001(b, c) \\
F(2,225)=6.66 \\
p=.002(a)\end{array}$ \\
\hline $\begin{array}{l}\text { Job Stress } \\
\text { Team Respect } \\
\text { Physical Work } \\
\text { Environment } \\
\text { Competence } \\
\text { Staffing }\end{array}$ & $\begin{array}{l}47.8(9.3) \\
10.0(2.7) \\
9.8(2.5) \\
14.3(3.1) \\
13.7(3.4)\end{array}$ & $\begin{array}{l}48.1(8.8) \\
9.7(2.6) \\
10.3(2.7) \\
13.5(2.8) \\
14.5(3.5)\end{array}$ & $\begin{array}{l}45.53 \\
(9.1) \\
9.1(2.6) \\
10.2(2.7) \\
12.1(2.9) \\
14.0(3.6)\end{array}$ & $\begin{array}{l}F(2,214) \\
=15.64 \\
p<.001 \quad(b, c) \\
F(2,214)= \\
11.14 \\
p<.001 \quad(b, c) \\
F(2,217)=4.98 \\
p=.008 \quad(a, b) \\
F(2,214)= \\
63.76 \\
p<.001 \quad(a, b, \\
c) \\
F(2,217)=7.27 \\
p<.001 \quad(a, c)\end{array}$ \\
\hline $\begin{array}{l}\text { Organizational } \\
\text { Commitment }\end{array}$ & $80.0(12.4)$ & $76.2(13.6)$ & $\begin{array}{l}77.2 \\
(13.6)\end{array}$ & $\begin{array}{l}F=(2,223)= \\
14.15 \\
p<.001 \quad(a, b)\end{array}$ \\
\hline $\begin{array}{l}\text { Quality of Nursing } \\
\text { Performance } \\
\text { Teaching/collaboration } \\
\text { Planning/evaluation } \\
\text { Leadership } \\
\text { Interpersonal relations/ } \\
\text { communication } \\
\text { Critical care } \\
\text { Professional development } \\
\text { Management/Outcomes }\end{array}$ & $\begin{array}{l}169.1(26.2) \\
28.6(6.1) \\
19.8(3.9) \\
14.3(2.9) \\
38.9(5.3) \\
16.9(5.3) \\
31.2(4.6) \\
19.2(6.0)\end{array}$ & $\begin{array}{l}180.7(23.7) \\
30.3(5.5) \\
21.2(3.5) \\
15.5(2.9) \\
40.1(4.8) \\
18.4(4.6) \\
32.5(4.5) \\
22.1(5.5)\end{array}$ & $\begin{array}{l}196.1 \\
(23.5) \\
33.5(5.4) \\
23.0(3.7) \\
16.6(2.4) \\
42.3(4.4) \\
21.1(4.4) \\
34.1(4.4) \\
25.3(5.2)\end{array}$ & $\begin{array}{l}F(2,218)= \\
114.71 \\
p<.001 \quad(a, b, \\
c) \\
F(2,220)= \\
78.34 \\
p<.001 \quad(a, b, \\
c) \\
F(2,220)=65.4 \\
p<.001 \quad(a, b, \\
c) \\
F(2,222)= \\
59.20 \\
p<.001 \quad(a, b, \\
c) \\
F(2,219)= \\
47.44 \\
p=.001 \quad(a) \\
p<.001 \quad(b, c) \\
F(2,223)= \\
107.22 \\
p<.001 \quad(a, b, \\
c) \\
F(2,223)= \\
35.97\end{array}$ \\
\hline
\end{tabular}

Journal of Continuing Education in Nursing, Vol. 42, No. 12 (December 2011): pg. 559-568. DOI. This article is (C) Slack Incorporated and permission has been granted for this version to appear in e-Publications@Marquette. Slack Incorporated does not grant permission for this article to be further copied/distributed or hosted elsewhere without the express permission from Slack Incorporated. 
NOT THE PUBLISHED VERSION; this is the author's final, peer-reviewed manuscript. The published version may be accessed by following the link in the citation at the bottom of the page.

\begin{tabular}{|l|l|l|l|}
\hline & & & $\begin{array}{l}\mathrm{p}<.001(\mathrm{a}, \mathrm{b}, \\
\mathrm{c}) \\
\mathrm{F}(2,223)= \\
\end{array}$ \\
& & $\begin{array}{l}101.46 \\
\mathrm{p}<.001(\mathrm{a}, \mathrm{b}, \\
\mathrm{c})\end{array}$ \\
\hline
\end{tabular}

Post-hoc analysis: $\mathrm{a}=$ Significant Differences between Time 1 \& Time $2 ; \mathrm{b}=$ Significant Differences between Time $1 \&$ Time 3; c = Significant Differences between Time 2 \& Time 3

Journal of Continuing Education in Nursing, Vol. 42, No. 12 (December 2011): pg. 559-568. DOI. This article is @ Slack Incorporated and permission has been granted for this version to appear in e-Publications@Marquette. Slack Incorporated does not grant permission for this article to be further copied/distributed or hosted elsewhere without the express permission from Slack Incorporated. 
NOT THE PUBLISHED VERSION; this is the author's final, peer-reviewed manuscript. The published version may be accessed by following the link in the citation at the bottom of the page.

Table 3: Comparisons of Group Differences in Participant Outcomes between Participants Completing All Measurement Points \{Complete Data Set $-\mathbf{N}=227$ ] and Participants Not Completing All Measurement Points [Incomplete Data Set $-\mathbf{N}=241$ ]

\begin{tabular}{|c|c|c|c|}
\hline Variable & $\begin{array}{c}\text { Time } 1 \\
\text { Baseline } \\
\text { Mean(SD) } \\
\text { Statistics }\end{array}$ & $\begin{array}{l}\text { Time } 2 \\
6 \text { Months } \\
\text { Mean(SD) } \\
\text { Statistics }\end{array}$ & $\begin{array}{c}\text { Time } 3 \\
12 \text { Months } \\
\text { Mean (SD) } \\
\text { Statistics }\end{array}$ \\
\hline $\begin{array}{l}\text { Clinical Decision Making } \\
\text { Complete Data Set } \\
\text { Incomplete Data Set }\end{array}$ & NS & NS & $\begin{array}{l}145.1(10.4) \\
140.9(10.5) \\
t(189)=-2.165 \\
p=.03\end{array}$ \\
\hline $\begin{array}{l}\text { Job Satisfaction } \\
\text { Complete Data Set } \\
\text { Incomplete Data Set }\end{array}$ & $\begin{array}{l}82.1(10.8) \\
78.4(11.7) \\
t(395)=-3.262 \\
p=.001\end{array}$ & $\begin{array}{l}81.0(10.9) \\
76.9(11.5) \\
t(336)=-3.172 \\
p=.002\end{array}$ & $\begin{array}{l}83.7(10.8) \\
80.8(10.4) \\
t(313)=-2.191 \\
p=.03\end{array}$ \\
\hline $\begin{array}{l}\text { Job Stress } \\
\text { Complete Data Set } \\
\text { Incomplete Data Set }\end{array}$ & $\begin{array}{l}47.8(9.3) \\
50.2(7.7) \\
t(391)=2.653 \\
p=.008\end{array}$ & $\begin{array}{l}48.1(8.8) \\
51.5(8.1) \\
t(334)=3.372 \\
p=.001\end{array}$ & $r$ \\
\hline $\begin{array}{l}\text { Organizational Commitment } \\
\text { Complete Data Set } \\
\text { Incomplete Data Set }\end{array}$ & $\begin{array}{l}80.0(12.4) \\
76.1(13.9) \\
t(395)=-3.064 \\
p=.002\end{array}$ & $\begin{array}{l}76.2(13.6) \\
72.6(13.6) \\
t(337)=-2.336 \\
p=.02\end{array}$ & $\begin{array}{l}77.2(13.6) \\
72.4(14.7) \\
t(309)=-2.682 \\
p=.008\end{array}$ \\
\hline $\begin{array}{l}\text { Quality of Nursing } \\
\text { Performance } \\
\text { Complete Data Set } \\
\text { Incomplete Data Set }\end{array}$ & NS & NS & NS \\
\hline
\end{tabular}

NS = Nonsignificant

Journal of Continuing Education in Nursing, Vol. 42, No. 12 (December 2011): pg. 559-568. DOI. This article is @ Slack Incorporated and permission has been granted for this version to appear in e-Publications@Marquette. Slack Incorporated does not grant permission for this article to be further copied/distributed or hosted elsewhere without the express permission from Slack Incorporated. 